\title{
Growth and biomass partitioning in mungbean with elevated carbon dioxide, phosphorus levels and cyanobacteria inoculation
}

\section{SUMIT KUMAR DEY*, B. CHAKRABARTI, R. PRASANNA, R. MITTAL, S. D. SINGH and H. PATHAK}

\author{
Centre for Environment Science and Climate Resilient Agriculture (CESCRA) \\ Indian Agricultural Research Institute, New Delhi-110 012, India \\ *Email : sumitdeyiari@gmail.com
}

\begin{abstract}
Mungbean is an important leguminous crop providing protein for the rural and urban poor in South and Southeast Asia. An experiment was conducted in free air carbon dioxide enrichment facility (FACE) ring to study the impact of increased $\mathrm{CO}_{2}$ level on growth and biomass partitioning in mungbean crop. The crop was grown under ambient $\left(400 \mu \mathrm{mol} \mathrm{mol}{ }^{-1}\right)$ and elevated $\mathrm{CO}_{2}$ concentration $(550 \mu \mathrm{mol}$ $\mathrm{mol}^{-1}$ ) with 5 doses of $\mathrm{P}$ with and without cyanobacterial inoculation. Elevated $\mathrm{CO}_{2}$ significantly increased biomass accumulation in mungbean crop which was further increased by $P$ and cyanobacteria application. Leaf biomass increased by $34.4 \%$ at increased $\mathrm{CO}_{2}$ level. Maximum biomass allocation to seeds was observed with $\mathrm{P}$ dose of $16 \mathrm{mg} \mathrm{kg}^{-1}$ soil in both ambient and elevated $\mathrm{CO}_{2}$ conditions. Allocation was more in high $\mathrm{CO}_{2}$ treatment. The study concludes that mungbean crop grown under elevated $\mathrm{CO}_{2}$ condition accumulates more biomass which gets further improved by application of $P$ nutrient and cyanobacteria inoculation.
\end{abstract}

Key wards: Mungbean, elevated $\mathrm{CO}_{2}$, phosphorus, cyanobacteria, biomass partitioning.

Mungbean [Vignaradiata (L.)Wilczek] is an important legume providing protein for the rural and urban poor in South and Southeast Asia. Due to its rapid growth and early maturity it is adopted in multiple cropping systems in the drier and warmer climates of tropics and sub-tropics. Mungbean seed has a high nutritive value containing about $22.5 \%$ protein, $1.3 \%$ fat and $60.4 \%$ of carbohydrate (Hussain et al., 2011). The legume crops like mungbean may be affected by the changing climate, caused due to increasing concentration of atmospheric carbon dioxide $\left(\mathrm{CO}_{2}\right)$ and other greenhouse gases (GHGs). Since 1750, $\mathrm{CO}_{2}$ concentration has increased from $278 \mathrm{ppm}$ (Pearson and Palmer, 2000) to currently 400 ppm (IPCC, 2014).

Due to their ability to fix atmospheric nitrogen, the legumes will get an added advantage over non-leguminous plants under elevated $\mathrm{CO}_{2}$ condition (Zanetti et al., 1996; Ross et al., 2004). Growth response of different crop species to varying $\mathrm{CO}_{2}$ concentration is different (Hunt et al., 1991; Poorter et al., 1996). There are reports of increased root length, root mass, and root diameter in soybean crop grown at increased $\mathrm{CO}_{2}$ level. According to Jin et al., (2012), elevated $\mathrm{CO}_{2}$ increased the biomass and length of root in legume on an average by $16 \%$ and $14 \%$ respectively. Impact of atmospheric $\mathrm{CO}_{2}$ enrichment on increase in peak leaf area index was also reported in leguminous crops like pigeon pea (Saha et al., 2012).

In order to get all the benefits of enriched $\mathrm{CO}_{2}$, adequate supply of other essential nutrients is required. Since phosphorus is an essential nutrient influencing N fixation in legumes hence $P$ application may have significant effect on legume crops in changing climatic conditions. Cyanobacteria also known as blue green algae (BGA) have a unique potential to contribute to the productivity of different agro-ecosystem under different ecological situations. Cyanobacteria are widely known to exist in rice ecosystem. But their beneficial effects were also observed on other crops. In wheat, application of cyanobacterial strains resulted in enhanced plant growth and yields (Karthikeyan et al., 2007; Nain et al., 2010). The objectives of the present study were to study the partitioning of biomass in mungbean crop under elevated $\mathrm{CO}_{2}$ condition with different $\mathrm{P}$ levels and cyanobacteria inoculation.

\section{MATERIALS AND METHODS}

An experiment was conducted during the kharif season (July to October) of 2014 in Indian Agricultural 
Research Institute farm, New Delhi, India $\left(28^{\circ} 35^{\prime} \mathrm{N}\right.$ and $77^{\circ} 12^{\prime} \mathrm{E}$ ). Mungbean crop (variety Pusa Vishal) was grown in pots both inside and outside the Free Air Carbon dioxide Enrichment (FACE) facility. The FACE ring is made up of eight horizontal pipes which releases $\mathrm{CO}_{2}$ enriched air at the crop canopy level. Diameter of the ring is $8 \mathrm{~m}$ Carbon dioxide $\left(\mathrm{CO}_{2}\right)$ concentration inside the ring was measured by nondispersive infrared gas analyzer (IRGA) and data was logged automatically in the computer at every 5 minutes interval. Carbon dioxide $\left(\mathrm{CO}_{2}\right)$ concentration inside the FACE ring was maintained at around $550 \pm 20 \mu \mathrm{mol} . \mathrm{mol}^{-1}$ while crops grown outside the FACE ring was subjected to ambient $\mathrm{CO}_{2}$ concentration i.e. $400 \mu \mathrm{mol} \mathrm{mol}^{-1}$. Recommended doses of nitrogen and potassium were applied through urea and murate of potash (MOP) as basal dose. In the study there were five different levels of phosphorus (P) like control $\mathrm{P}$ (No phosphatic fertilizer applied), $75 \%$ of recommended dose of $\mathrm{P}, 100 \%$ of recommended dose of $\mathrm{P}, 125 \%$ of recommended dose of $P$ and $150 \%$ of recommended dose of P. P was applied through single super phosphate (SSP) fertilizer. Mungbean seeds were inoculated with crop specific Rhizobium inoculants available in the Division of Microbiology and cyanobacterium - Calothrix sp. inoculation was done in soil.

Plants are collected by destructive sampling at 25, 45 and 65 days after showing (DAS)and above ground biomass were recorded in those stages. Leaf, stem, root and seeds were collected during harvesting stage of the crop (65 DAS) and their weight was recorded. Nodules were extracted from roots at 25 and 45 DAS and their biomass was recorded.

The design of the experiment was factorial completely randomized design (CRD) with 20 treatments. Statistical analysis of the data was performed using SAS (ver. 9.3) statistical package developed by SAS Institute Inc.

\section{RESULTS AND DISCUSSION}

\section{Biomass Partitioning}

Leaf biomass : Elevated $\mathrm{CO}_{2}$ level, cyanobacterial inoculation as well as $\mathrm{P}$ application had significant effect on the leaf biomass of the crop. Elevated $\mathrm{CO}_{2}$ increased leaf biomass by $34.4 \%$ at 65 DAS. Cyanobacterial inoculation also increased leaf biomass of the crop. Leaf biomass was $4.36 \mathrm{~g} \mathrm{plant}^{-1}$ in without cyanobactria treatment while in treatment with cyanobacterial inoculation leafbiomass was $4.83 \mathrm{~g} \mathrm{plant}^{-1}$. Application of P significantly increased leaf biomass over control. The interactive effect of $\mathrm{CO}_{2}$ and phosphorus significantly increased leaf biomass of the crop throughout the crop growth period.

Similar results were reported by Sharma and Sengupta (1990) who reported that the extra carbon fixed by mungbean crop in elevated $\mathrm{CO}_{2}$ condition gets translocated to the growing organs resulting in higher biomass of the crop.

Stem biomass : Stem weight of mungbean crop ranged from 2.90 to 7.74 g plant $^{-1}$ in different treatments (Fig. 1). Elevated $\mathrm{CO}_{2}$ level also increased stem biomass of the crop. Stem weight of mungbean crop was $6.50 \mathrm{~g} \mathrm{plant}^{-1}$ under high $\mathrm{CO}_{2}$ level while in ambient $\mathrm{CO}_{2}$ treatment stem biomass was 5.12 g plant $^{-1}$. Cyanobacterial inoculation also increased stem biomass of the crop by $10.5 \%$. Application of P significantly increased stem weight of the crop over control. Highest stem biomass was recorded in treatment with $20 \mathrm{mg} \mathrm{kg}^{-1} \mathrm{P}$. Stem weight was $6.78 \mathrm{~g}$ plant ${ }^{-1}$ with P dose of $20 \mathrm{mg} \mathrm{kg}^{-1}$ soil.

Root biomass : Increased $\mathrm{CO}_{2}$ level had significant improved root growth of the plant. Root weight in ambient $\mathrm{CO}_{2}$ condition was $0.41 \mathrm{~g} \mathrm{plant}^{-1}$ while in elevated $\mathrm{CO}_{2}$ treatment root weight was $0.61 \mathrm{~g} \mathrm{plant}^{-1}$. Biomass allocation to mungbean roots also increased under high $\mathrm{CO}_{2}$ condition. At harvesting stage of the crop $3.4 \%$ of total biomass was allocated to roots under elevated $\mathrm{CO}_{2}$ condition while in ambient treatment $3 \%$ of the total biomass was partitioned to roots in mungbean crop. Several studies have shown increase in root weight under elevated $\mathrm{CO}_{2}$ condition in several crops including wheat, black gram (Vanaja et al., 2007), and soybean (Del Castillo et al., 1989). Cyanobacterial inoculation significantly increased root weight of the crop. A study by Liu-Shi Ming and Liang-Shi Zhong (1998) revealed that cyanobacterial extracts increased root growth and number of roots in mungbean crop.

Increase in $\mathrm{P}$ dose significantly increased root growth of the crop which was evident from significantly higher root biomass at higher P levels throughout the crop growth period. Maximum root weight $\left(0.60 \mathrm{~g} \mathrm{plant}^{-1}\right)$ of the crop was observed with P dose of $20 \mathrm{mg} \mathrm{kg}^{-1}$ soil.

Above ground biomass : Increased $\mathrm{CO}_{2}$ level has resulted in significant rise in above ground biomass of the crop under high $\mathrm{CO}_{2}$ condition as compared to ambient one. Cyanobacterial inoculation also showed high above ground biomass in all the crop growth stages. At harvesting stage of the cropi.e. at 65 DAS, above ground biomass was $17.13 \mathrm{~g}$ plant $^{-1}$ in high $\mathrm{CO}_{2}$ treatments while in ambient condition above ground biomass was $13.05 \mathrm{~g} \mathrm{plant}^{-1}$ (Table 1). Increased $\mathrm{CO}_{2}$ concentration enhanced above ground biomass by 
Table 1: Impact of elevated $\mathrm{CO}_{2}$, cyanobacteral inoculation and phosphorus doses on above ground biomass plant ${ }^{-1}(\mathrm{~g}$ plant $^{-1}$ ) at 25, 45 and 65 DAS in mungbean.

\begin{tabular}{|c|c|c|c|c|c|}
\hline $\begin{array}{l}\text { P Levels } \\
\left(\mathrm{mg} \mathrm{kg}^{-1} \text { soil) }\right.\end{array}$ & Phosphorus & Ambient $\mathrm{CO}_{2}$ & Mean elevated $\mathrm{CO}_{2}$ & Without Cyanobacteria & With Cyanobacteria \\
\hline \multicolumn{6}{|c|}{$25 \mathrm{DAS}$} \\
\hline Control P & $1.48^{\mathrm{E}}$ & $1.32^{\mathrm{I}}$ & $1.65^{\mathrm{G}}$ & $1.38^{\mathrm{H}}$ & $1.59^{\mathrm{G}}$ \\
\hline 8 & $1.71^{\mathrm{D}}$ & $1.51^{\mathrm{H}}$ & $1.91^{\mathrm{F}}$ & $1.60^{\mathrm{G}}$ & $1.81^{\mathrm{F}}$ \\
\hline 12 & $2.18^{\mathrm{C}}$ & $1.90^{\mathrm{F}}$ & $2.46^{\mathrm{C}}$ & $2.15^{\mathrm{E}}$ & $2.22^{\mathrm{D}}$ \\
\hline 16 & $2.39^{\mathrm{B}}$ & $2.03^{\mathrm{E}}$ & $2.75^{\mathrm{B}}$ & $2.32^{\mathrm{C}}$ & $2.46^{\mathrm{B}}$ \\
\hline 20 & $2.68^{\mathrm{A}}$ & $2.21^{\mathrm{D}}$ & $3.14^{\mathrm{A}}$ & $2.51^{\mathrm{B}}$ & $2.85^{\mathrm{A}}$ \\
\hline Mean & $1.79^{\mathrm{B}}$ & $2.38^{\mathrm{A}}$ & $1.99^{\mathrm{B}}$ & $2.19^{\mathrm{A}}$ & \\
\hline \multicolumn{6}{|c|}{45 DAS } \\
\hline Control P & $6.12^{\mathrm{E}}$ & $5.32^{\mathrm{G}}$ & $6.92^{\mathrm{FG}}$ & $5.69^{\mathrm{A}}$ & $6.55^{\mathrm{A}}$ \\
\hline 8 & $9.24^{\mathrm{D}}$ & $8.11^{\mathrm{F}}$ & $10.38^{\mathrm{E}}$ & $8.34^{\mathrm{A}}$ & $10.15^{\mathrm{A}}$ \\
\hline 12 & $12.46^{\mathrm{C}}$ & $10.88^{\mathrm{E}}$ & $14.05^{\mathrm{BC}}$ & $11.49^{\mathrm{A}}$ & $13.43^{\mathrm{A}}$ \\
\hline 16 & $13.56^{\mathrm{B}}$ & $11.98^{\mathrm{DE}}$ & $15.14^{\mathrm{B}}$ & $12.57^{\mathrm{A}}$ & $14.55^{\mathrm{A}}$ \\
\hline 20 & $15.24^{\mathrm{A}}$ & $13.18^{\mathrm{DC}}$ & $17.30^{\mathrm{A}}$ & $14.49^{\mathrm{A}}$ & $15.98^{\mathrm{A}}$ \\
\hline Mean & $9.89^{\mathrm{B}}$ & $12.76^{\mathrm{A}}$ & $10.52^{\text {в }}$ & $12.13^{\mathrm{A}}$ & \\
\hline \multicolumn{6}{|c|}{65 DAS } \\
\hline Control P & $9.78^{\mathrm{D}}$ & $7.98^{\mathrm{A}}$ & $11.59^{\mathrm{A}}$ & $8.72^{\mathrm{A}}$ & $10.85^{\mathrm{A}}$ \\
\hline 8 & $14.94^{\mathrm{C}}$ & $12.80^{\mathrm{A}}$ & $17.07^{\mathrm{A}}$ & $14.03^{\mathrm{A}}$ & $15.84^{\mathrm{A}}$ \\
\hline 12 & $16.03^{\text {в }}$ & $13.90^{\mathrm{A}}$ & $18.17^{\mathrm{A}}$ & $15.24^{\mathrm{A}}$ & $16.82^{\mathrm{A}}$ \\
\hline 16 & $16.76^{\mathrm{B}}$ & $14.76^{\mathrm{A}}$ & $18.75^{\mathrm{A}}$ & $15.97^{\mathrm{A}}$ & $17.55^{\mathrm{A}}$ \\
\hline 20 & $17.95^{\mathrm{A}}$ & $15.82^{\mathrm{A}}$ & $20.08^{\mathrm{A}}$ & $17.11^{\mathrm{A}}$ & $18.78^{\mathrm{A}}$ \\
\hline Mean & $13.05^{\text {в }}$ & $17.13^{\mathrm{A}}$ & $14.21^{\mathrm{B}}$ & $15.97^{\mathrm{A}}$ & \\
\hline
\end{tabular}

Same letters are not significantly different.

Table 2: Impact of elevated $\mathrm{CO}_{2}$, cyanobacteral inoculation and phosphorus doses on fresh weight of nodule plant ${ }^{-1}$ $\left(\mathrm{mg} \mathrm{plant}^{-1}\right)$ at 25,45 and 65 DAS in mungbean.

\begin{tabular}{lccccc}
\hline $\begin{array}{l}\text { P Levels } \\
\left(\mathrm{mg} \mathrm{kg}{ }^{-1} \text { soil }\right)\end{array}$ & Phosphorus & Ambient $\mathrm{CO}_{2}$ & Mean elevated $\mathrm{CO}_{2}$ & Without Cyanobacteria & With Cyanobacteria \\
\hline Control P & $180.3^{\mathrm{E}}$ & $125.3^{\mathrm{G}}$ & $235.3^{\mathrm{DE}}$ & $161.2^{\mathrm{A}}$ & $199.4^{\mathrm{A}}$ \\
$\mathbf{8}$ & $230.5^{\mathrm{D}}$ & $159.9^{\mathrm{FG}}$ & $301.1^{\mathrm{C}}$ & $211.7^{\mathrm{A}}$ & $249.3^{\mathrm{A}}$ \\
$\mathbf{1 2}$ & $290.1^{\mathrm{C}}$ & $198.6^{\mathrm{FE}}$ & $381.7^{\mathrm{B}}$ & $274.0^{\mathrm{A}}$ & $306.2^{\mathrm{A}}$ \\
$\mathbf{1 6}$ & $321.2^{\mathrm{B}}$ & $228.3^{\mathrm{DE}}$ & $414.0^{\mathrm{B}}$ & $298.7^{\mathrm{A}}$ & $343.6^{\mathrm{A}}$ \\
$\mathbf{2 0}$ & $371.2^{\mathrm{A}}$ & $265.4^{\mathrm{DC}}$ & $477.0^{\mathrm{A}}$ & $353.5^{\mathrm{A}}$ & $388.9^{\mathrm{A}}$ \\
Mean & $195.5^{\mathrm{B}}$ & $361.8^{\mathrm{A}}$ & $259.8^{\mathrm{B}}$ & $297.5^{\mathrm{A}}$ & \\
& & $45 \mathrm{DAS}$ & & $367.4^{\mathrm{A}}$ \\
$\mathbf{C o n t r o l ~ P}$ & $339.5^{\mathrm{D}}$ & $250.8^{\mathrm{G}}$ & $428.2^{\mathrm{DFE}}$ & $311.6^{\mathrm{A}}$ & $470.0^{\mathrm{A}}$ \\
$\mathbf{8}$ & $449.3^{\mathrm{C}}$ & $338.4^{\mathrm{GF}}$ & $560.1^{\mathrm{DC}}$ & $428.5^{\mathrm{A}}$ & $530.9^{\mathrm{A}}$ \\
$\mathbf{1 2}$ & $541.1^{\mathrm{B}}$ & $412.1^{\mathrm{FE}}$ & $670.1^{\mathrm{BC}}$ & $551.3^{\mathrm{A}}$ & $701.1^{\mathrm{A}}$ \\
$\mathbf{1 6}$ & $644.4^{\mathrm{A}}$ & $499.6^{\mathrm{DE}}$ & $789.2^{\mathrm{BA}}$ & $587.7^{\mathrm{A}}$ & $743.1^{\mathrm{A}}$ \\
$\mathbf{2 0}$ & $718.9^{\mathrm{A}}$ & $543.3^{\mathrm{DCE}}$ & $894.5^{\mathrm{A}}$ & $694.7^{\mathrm{A}}$ & $562.5^{\mathrm{A}}$ \\
Mean & $408.8^{\mathrm{B}}$ & $668.4^{\mathrm{A}}$ & $514.8^{\mathrm{B}}$ & & \\
\hline
\end{tabular}

Same letters are not significantly different. 
Table 3: Impact of elevated $\mathrm{CO}_{2}$, cyanobacteral inoculation and phosphorus doses on seed yield $\left(\mathrm{g} \mathrm{plant}^{-1}\right)$ of mungbean crop.

\begin{tabular}{lccccc}
\hline $\begin{array}{l}\text { P Levels } \\
\left(\mathrm{mg} \mathrm{kg}{ }^{-1} \text { soil }\right)\end{array}$ & Phosphorus & ${\text { Ambient } \mathrm{CO}_{2}}$ & Mean elevated $\mathrm{CO}_{2}$ & Without Cyanobacteria & With Cyanobacteria \\
\hline $\mathbf{C o n t r o l ~ P}$ & $2.7^{\mathrm{E}}$ & $2.1^{\mathrm{A}}$ & $3.3^{\mathrm{A}}$ & $2.4^{\mathrm{A}}$ & $3.0^{\mathrm{A}}$ \\
$\mathbf{8}$ & $4.6^{\mathrm{D}}$ & $4.0^{\mathrm{A}}$ & $5.3^{\mathrm{A}}$ & $4.3^{\mathrm{A}}$ & $5.0^{\mathrm{A}}$ \\
$\mathbf{1 2}$ & $5.0^{\mathrm{C}}$ & $4.4^{\mathrm{A}}$ & $5.7^{\mathrm{A}}$ & $4.7^{\mathrm{A}}$ & $5.4^{\mathrm{A}}$ \\
$\mathbf{1 6}$ & $5.4^{\mathrm{B}}$ & $4.7^{\mathrm{A}}$ & $6.1^{\mathrm{A}}$ & $5.0^{\mathrm{A}}$ & $5.7^{\mathrm{A}}$ \\
$\mathbf{2 0}$ & $5.7^{\mathrm{A}}$ & $5.0^{\mathrm{A}}$ & $6.4^{\mathrm{A}}$ & $5.3^{\mathrm{A}}$ & $6.0^{\mathrm{A}}$ \\
Mean & & $4.0^{\mathrm{B}}$ & $5.4^{\mathrm{A}}$ & $4.3^{\mathrm{B}}$ & $5.0^{\mathrm{A}}$ \\
\hline
\end{tabular}

Same letters are not significantly different.

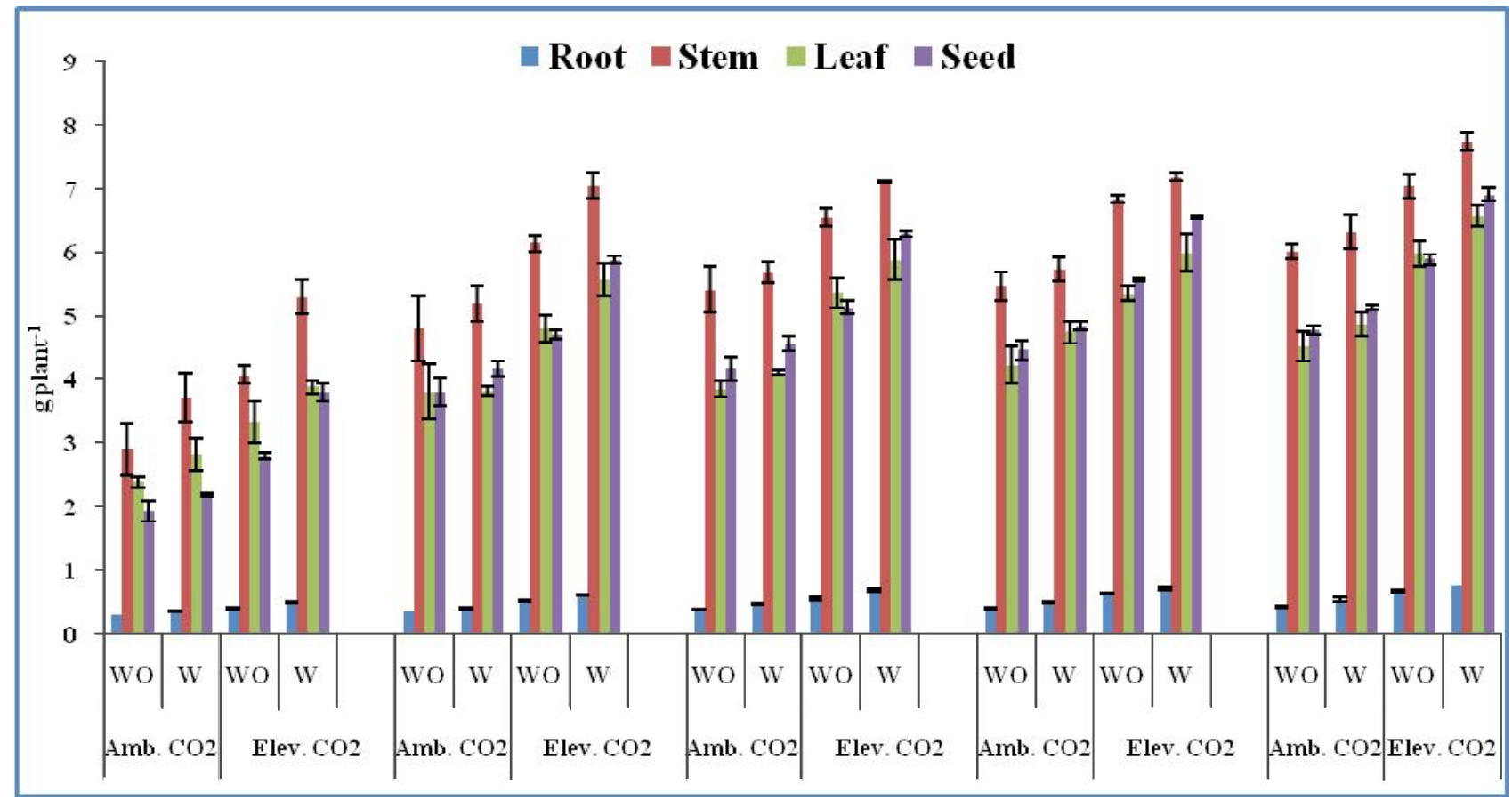

Fig 1: Interactive effect of elevated carbon dioxide, cyanobacterial inoculation and phosphorus doses on biomass of root, stem, leaf and seed per plant in Mungbean at 65 DAS (WO-Without Cyanobacteria, W-With Cyanobacteria).

$33 \%, 29 \%$ and $31.3 \%$ than ambient $\mathrm{CO}_{2}$ level at 25,45 and 65 DAS respectively. Papplication also significantly affected aboveground biomass of the crop. At 25, 45 and 65 DAS highest above ground biomass $(2.68,15.24$ and $17.95 \mathrm{~g}$ plant ${ }^{-1}$ ) was observed with P dose of $20 \mathrm{mg} \mathrm{kg}^{-1}$ soil (Table 1). The interactive effect of $\mathrm{CO}_{2}$ and phosphorus levels on above ground biomass was observed at 25 and 45 DAS.

Increased crop biomass at elevated $\mathrm{CO}_{2}$ level was primarily attributed to the fact that more amounts of carbon assimilated by the crop under high $\mathrm{CO}_{2}$ concentration was partitioned towards the growing organs leading to more leaf, stem, root, seed and ultimately higher above ground biomass of the crop. According to Saha et al.,(2012) increased partitioning of photosynthate led to higher biomass and seed yield in pigeonpea crop under elevated $\mathrm{CO}_{2}$ condition.
Partitioning of accumulated above ground biomass to seeds was higher $(31.5 \%)$ in elevated $\mathrm{CO}_{2}$ condition than ambient treatment $(30.7 \%)$.

Nodule biomass : Elevated $\mathrm{CO}_{2}$ as well as cyanobacterial inoculation significantly increased nodule weight of plants throughout the crop growth period. Nodule growth was maximum at 45 DAS (Table 2). At this stage nodule weight was $668.4 \mathrm{mg}$ plant ${ }^{-1}$ under increased $\mathrm{CO}_{2}$ concentration while in ambient condition nodule weight was $408.8 \mathrm{mg}$ plant $^{-1}$ (Table 2). Earlier workers also reported that nodule biomass in legumes increased by $46 \%$ in response to enriched $\mathrm{CO}_{2}$ (Jin et al., 2012). In cyanobacteria inoculated treatments nodule biomass was $562.5 \mathrm{mg} \mathrm{plant}^{-1}$ while in without cyanobacteria treatment nodule weight was $514.8 \mathrm{mg}$ plant $^{-1}$ (Table 2). Increasing doses of P also significantly 
increased nodule growth in mungbean plants (Table 2). At 25 DAS nodule weight increased significantlywith increased $P$ dose with maximum nodule weight (371.2 $\mathrm{mg} \mathrm{plant}^{-1}$ ) recorded at $\mathrm{P}$ dose of $20 \mathrm{mg} \mathrm{kg}^{-1}$ soil (Table 2). But at $45 \mathrm{DAS}$, application of P upto $16 \mathrm{mg} \mathrm{kg}^{-1}$ soil significantly increased nodule biomass of the crop. The interactive effect of elevated $\mathrm{CO}_{2}$ along with high doses of $\mathrm{P}$ further improved the nodule growth in mungbean crop. According to Israel (1987), phosphorus has specific roles in nodule initiation, growth, and functioning in soybean crop.

\section{Yield}

Elevated $\mathrm{CO}_{2}$ significantly increased seed yield of mungbeancrop. Seed yield ranged from 1.9 to 6.9 g plant $^{-1}$ in different treatments (Fig. 1). Vanaja et al (2010) also found that increased level of $\mathrm{CO}_{2}$ increased both biomass and seed yield of pigeonpea crop as compared to ambient condition. Application of cyanobacterial inoculation also increased seed yield with $5 \mathrm{~g}$ plant $^{-1}$ seed yield in cyanobacteria applied treatments and $4.3 \mathrm{~g} \mathrm{plant}^{-1}$ seed yield in without cyanobacteria treatment (Table 3 ). Increase in $\mathrm{P}$ dose improved seed yield in both ambient and elevated $\mathrm{CO}_{2}$ treatments. Maximum seed yield $\left(5.4 \mathrm{~g} \mathrm{plant}^{-1}\right)$ was observed with $\mathrm{P}$ dose of $20 \mathrm{mg} \mathrm{kg}^{-1}$ soil (Table 3 ). Partitioning of accumulated biomass to seeds also improved with $\mathrm{P}$ application. Maximum biomass allocation to mungbean seeds was observed with $\mathrm{P}$ dose of $16 \mathrm{mg} \mathrm{kg}^{-1}$ soil in both ambient and elevated $\mathrm{CO}_{2}$ condition. But the allocation was more in high $\mathrm{CO}_{2}$ treatment. High $\mathrm{CO}_{2}$ concentration along with cyanobacterial inoculation further improved seed yield of mungbean crop. Jagannath et al. (2002) also showed that use of BGA in chickpea crop has resulted in higher biomass yield and seed yield of the crop.

\section{CONCLUSIONS}

Elevated $\mathrm{CO}_{2}$ condition significantly increased biomass accumulation in mungbean crop. Higher amount of carbon assimilated by the crop under high $\mathrm{CO}_{2}$ concentration has increased partitioning of more assimilates to the growing organs like leaf, stem, root and seed. Cyanobacterial inoculation as well as $\mathrm{P}$ application also improved growth of leaf, stem, roots and ultimately seed yield of the crop. Partitioning of accumulated biomass to seeds was also found to be more in elevated $\mathrm{CO}_{2}$ treatment than ambient treatment. The study concludes that mungbean crop grown under elevated $\mathrm{CO}_{2}$ condition accumulates more biomass which gets further improved by application of $P$ nutrient and cyanobacteria inoculation. Partitioning of accumulated assimilates to seeds was also higher in high $\mathrm{CO}_{2}$ concentration. The $\mathrm{P}$ application caused more biomass translocation to mungbean seeds under elevated $\mathrm{CO}_{2}$ condition.

\section{ACKNOWLEDGEMENTS}

The authors thank Indian Council of Agricultural Research (ICAR), New Delhi for providing financial and other necessary supports for conducting the study. This work was supported by Centre for Environment Science and Climate Resilient Agriculture (CESCRA) and Division of Microbiology, Indian Agricultural Research Institute (IARI), New Delhi.

\section{REFERENCES}

Del Castillo, D. Acock, B. Reddy, V.R. and Acock, M.C. (1989). Elongation and branching of roots on soybean plants in a carbon dioxide enriched aerial environment. Agron. J.,81:692-695.

Hunt, R. Hand, D.W. Hannah, M.A. and Neal, A.M. (1991).Response to $\mathrm{CO}_{2}$ enrichment in 27 herbaceous species.Funct. Ecol.,5:410-421.

Hussain, F. Malik,A.U. Haji, M.A.and Malghani,A.L. (2011). Growth and yield response of two cultivars of mungbean (Vigna radiata) to different potassium levels. J. Anim. Plant Sci.,21(3):622-625.

IPCC. (2014). Summary for Policymakers, In: Climate Change, Mitigation of Climate Change. Contribution of Working Group III to the Fifth Assessment Report of the Intergovernmental Panel on Climate Change.Cambridge UniversityPress, Cambridge, United Kingdom and New York, NY, USA.1-31.

Israel, D.W. (1987). Investigation of the role of phosphorus in symbiotic dinitrogen fixation.Plant Physiol., 84:835840.

Jagannath, S.B.A. Umapati, D. and Eshwarlal, S. (2002).Algalization studies on chickpea (Cicerarietinum L). In: "Biotechnology of microbes and sustainable utilization."(Eds. R.C. Rajak). Pp.145-150.(Microbial technology for sustainable development and productivity,Jabalpur, India).

Jin, J. Tang, C. Armstrong, R. and Sale, P.(2012). Phosphorus supply enhances the response of legumes to elevated $\mathrm{CO}_{2}$ (FACE) in a phosphorus-deficient Vertisol. Plant Soil., 358:86-99. 
Karthikeyan, N. Prasanna, R. Lata, N. and Kaushik, B.D. (2007).Evaluating the potential of plant growth promoting cyanobacteria as inoculants for wheat.Eur JSoil Biol., 43:23-30.

Liu, ShiMing. and Liang, ShiZhong.(1998). Effect of extract from Nostoc commune cells on the growth of sprouts and seedlings of mungbean (Phaseolusradiatus). Plant Physiol. Comm., 29(6):429-431.

Nain, L. Rana, A. Joshi, M. Shrikrishna, J.D. Kumar, D. Shivay, Y.S. Paul, S. and Prasanna, R. (2010). Evaluation of synergistic effects of bacterial and cyanobacterial strains as biofertilizers for wheat. Plant Soil., 331:217-230.

Pearson, P.N. and Palmer, M.R. (2000).Atmospheric carbon dioxide concentrations over the past 60 million years.Nature.,406:695-699.

Poorter, H.Roumet, C. and Campbell, B. D. (1996). Interspecific variation in the growth response of plants to elevated $\mathrm{CO}_{2}$ : a search for functional types. In: "Carbon dioxide, populations, and communities”. (Eds.KoÈrner, C. Bazzaz, F.A) pp 375 \pm 412 (Academic Press, San Diego).

Ross, D.J. Newton, P.C.D. and Tate, K.R.(2004).Elevated $\left(\mathrm{CO}_{2}\right)$ effects on herbage production and soil carbon and nitrogen pools and mineralization in a species-rich, grazed pasture on a seasonally dry sand.Plant Soil.,260:183-196.
Saha, S. Sehgala, V.K. Nagarajana, S. and Pal, M. (2012). Impact of elevated atmospheric $\mathrm{CO}_{2}$ on radiation utilization and related plant biophysical properties in pigeon pea (Cajanuscajan L.). Agric. Forest. Meteorol.158159:63-70.

Sharma, A. and Sengupta, U.K.(1990). Carbon dioxide enrichment effect on photosynthesis and related enzymes in Vigna radiateWilczek. Indian J. Plant Physiol.,33:340-346.

Vanaja, M,Ram Reddy, P.R, Lakshmi, N.J, Abdul Razak, S.K, Vagheera, P. Archana, G. Yadav, S.K, Maheswari, M. and Venkateswarlu, B. (2010) Response of seed yield and its components of red gram (Cajanus cajan L. Millsp.) to elevated $\mathrm{CO}_{2}$.Plant Soil Environ.,56(10):458-462.

Vanaja, M. Raghuram, P. Reddy, N. Lakshmi, J. Maheswari, M. Vagheera, P. Ratnakumar, M. Jyothi, S.K. Yadav, S.K. and Venkateswarlu, B. (2007). Effect of elevated atmospheric $\mathrm{CO}_{2}$ concentrations on growth and yield of blackgram (VignamungoL. Hepper) a rain fed pulse crop. Plant Soil Environ.,53:81-88.

Zanetti, S. Hartwig, U.A. Luscher, A. Hebeisen, T. Frehner, M. Fischer, B.U. Hendrey, G.R. Blum, H. and Nosberger, J. (1996). Stimulation of symbiotic $\mathrm{N}_{2}$ fixation in Trifoliumrepens $\mathrm{L}$. under elevated atmospheric ${ }_{\mathrm{p}} \mathrm{CO}_{2}$ in a grassland ecosystem. Plant Physiol.,112:575-583. 